Article

\title{
Life Cycle Assessment of Iberian Traditional Pig Production System in Spain
}

\author{
Javier García-Gudiño ${ }^{1, *}$, Alessandra N. T. R. Monteiro ${ }^{2}$, Sandrine Espagnol $^{3}$, \\ Isabel Blanco-Penedo ${ }^{4}\left[\right.$ and Florence Garcia-Launay ${ }^{2}$ \\ 1 Animal Welfare Program, Institute of Agrifood Research and Technology-IRTA, 17121 Monells, Spain \\ 2 PEGASE, INRAE, Agrocampus Ouest, 35590 Saint-Gilles, France; \\ a_monteiro@zootecnista.com.br (A.N.T.R.M.); florence.garcia-launay@inra.fr (F.G.-L.) \\ 3 IFIP, Institut du porc, 35651 Le Rheu, France; sandrine.espagnol@ifip.asso.fr \\ 4 Department of Clinical Sciences, SLU, SE-750 07 Uppsala, Sweden; isabel.blanco.penedo@slu.se \\ * Correspondence: javier.garciag@juntaex.es
}

Received: 26 December 2019; Accepted: 13 January 2020; Published: 15 January 2020

check for updates

\begin{abstract}
Traditional Iberian pig production is characterized by outdoor systems that produce animals fed with natural resources. The aim of this study was to assess the environmental impacts of such systems through Life Cycle Assessment. Environmental impacts were analysed per kilogram of live weight at farm gate. Iberian pig production in montanera had the lowest impacts for climate change (CC), acidification (AC), eutrophication (EU) and cumulative energy demand (CED), being $3.4 \mathrm{~kg}$ $\mathrm{CO}_{2}$ eq, 0.091 molc $\mathrm{H}^{+}$eq, $0.046 \mathrm{~kg} \mathrm{PO}_{4}{ }^{3-}$ eq, and $20.7 \mathrm{MJ}$, respectively, due to the strict use of natural resources (acorns and grass) during the fattening period. As Iberian farms had a greater dependence on compound feed in cebo campo, environmental impacts on CC, AC, EU and CED were 22, 17, 95 and $28 \%$ higher, respectively, than with montanera. For land occupation (LO), however, cebo campo had a lower impact $\left(31.6 \mathrm{~m}^{2} \cdot\right.$ year $)$ than montanera $\left(43.0 \mathrm{~m}^{2} \cdot\right.$ year $)$ system. Traditional Iberian pig production systems have environmental impacts higher than conventional systems studied in literature but are similar to other traditional systems. Based on the present assessment, it is necessary to account for the contribution of emissions resulting from the consumption of natural resources to avoid the underestimation of environmental impacts.
\end{abstract}

Keywords: extensive pig production; environmental impacts; natural resources; local breed

\section{Introduction}

Environmental impacts derived from livestock production have received increasing attention in recent times [1], with pig production being one of the main contributors [2]. However, extensive systems generate a lower level of pollution than other livestock systems [3]. Many studies estimated the level of these impacts for conventional pig production through Life Cycle Assessment (LCA), which is the most recognized methodology to do so [4]. One of the main outcomes was that feed production was the main contributor to most of the main environmental impacts investigated, i.e., climate change, energy demand and land occupation $[5,6]$.

Recent studies focusing on alternative systems, such as organic [7-10] or traditional pig production $[11,12]$ highlighted that such systems usually have higher impacts than conventional ones. Indeed, they use more compound feeds than conventional systems and fatten pigs to a heavier live weight of elder pigs at slaughter. However, few studies suggested that lower impacts may be achieved by outdoor traditional productions with local breeds [13-15], given that they strongly rely on the consumption of natural resources available on grasslands and rangelands (e.g., acorns, chestnuts, grass). 
In the Southwest of Spain, Iberian pig is an autochthonous breed raised in the ecosystem called dehesa. Dehesa is defined as open oak forests with ground cover of herbaceous species and sparse shrubs [16]. Extensive production and the use of natural resources by Iberian pigs in dehesa generate high quality foods, mainly dry-cured meat products [17]. Consumer's perception of this livestock production system (pigs raised outdoors) is positive when compared to conventional systems [18]. The use of natural resources may be exclusive (montanera) or partial (cebo campo) during the fattening period. We hypothesized that pig production systems highly relying on natural resources like traditional Iberian system with fattening in montanera presented lower environmental impacts than systems like cebo campo that depend more on compound feeds.

Therefore, the first objective of this study was to evaluate the environmental impacts of traditional Iberian systems, while accounting for the contribution of emissions resulting from the consumption of natural resources (acorns and grass). The second objective was to quantify the reduction of environmental impacts when relying on natural resources and to determine if Iberian pig systems with montanera can result in similar impacts to those of conventional systems (per kg of live weight). For these purposes, LCA of traditional Iberian systems was conducted, with two case studies on farms with montanera (fattening exclusively with natural resources) and farms with both montanera and cebo campo systems (cebo campo with provision of compound feed for finishing).

\section{Materials and Methods}

\subsection{Description of the System}

The system considered is the traditional production of Iberian pigs in the Southwest of Spain, relying on the dehesa ecosystem for the finishing period. Dehesa is defined as an ecosystem where the surface is occupied by pasture and Quercus open woodlands. This ecosystem combines livestock, agricultural and forestry resources. Approximately, dehesa produces 1.23 million Iberian pigs per year [19]. The system is characterized by the use of Iberian pure sows and either Iberian pure, Iberian crossbred or Duroc boars. At the breeding season, dry sows and gilts are kept into management corrals that contain one or several boars for a given period (minimum 25 days). Artificial insemination is being used in several farms. After this period, the sows are kept in groups outdoors, consuming rangeland resources. The breeding animals are supplemented with concentrate or by-products depending on the available rangeland resources and their productive state [17]. The farrowing management is not generally a standard operating practice. The farrowing sows can stay either in traditional huts with outdoor access (sows can eat natural resources) or in farrowing crates [20]. This breed weans 7.26 piglets per litter and farrows 2.4 times per year in intensive systems [21]. With the traditional production, the number of weaned piglets is 6.38 per litter and the sows farrow twice a year [22]. According to the month of birth, the piglets are managed differently (Figure 1). Animals born in autumn are intended for montanera while animals born in spring are sold as weaned piglets or destined for cebo campo. Piglets are weaned at 7-8 weeks in traditional systems, compared to 3-4 weeks in intensive management conditions. The animals are classified as piglets until $23 \mathrm{~kg}$ of live weight. Then, Iberian pig production can have two different purposes: piglet production or weaning to slaughtering. If the piglets stay on the farm, the next phase is the growing period where the animals reach $100 \mathrm{~kg}$ of live weight in approximately one year [17]. In this phase, the growing pigs are kept on large areas of rangeland or small outdoor pens where they are supplied with compound feed and have access to rangeland resources. There are two different fattening phases, montanera and cebo campo, corresponding to different periods of the year (Figure 1). The minimum duration required for the fattening phase is 60 days and the pigs are slaughtered at $165 \mathrm{~kg}$ of average live weight. In montanera, fatteners consume only grass and acorns from October to March. The surface per animal ranges from 0.8 to 4 ha depending on the density of the forested area. In cebo campo, the finishing pigs are fed with pasture and compound feed. Animals are kept outdoor on 1 ha for 15 Iberian pigs [23]. Over half of Iberian pigs' production is fattened in montanera $(51.89 \%)$, while the rest $(48.11 \%)$ is fattened in cebo campo. Half of the pigs in 
montanera are Iberian pure (47\%), whereas Iberian crossbred represents the mainstream genetics (91\%) in cebo campo [19].

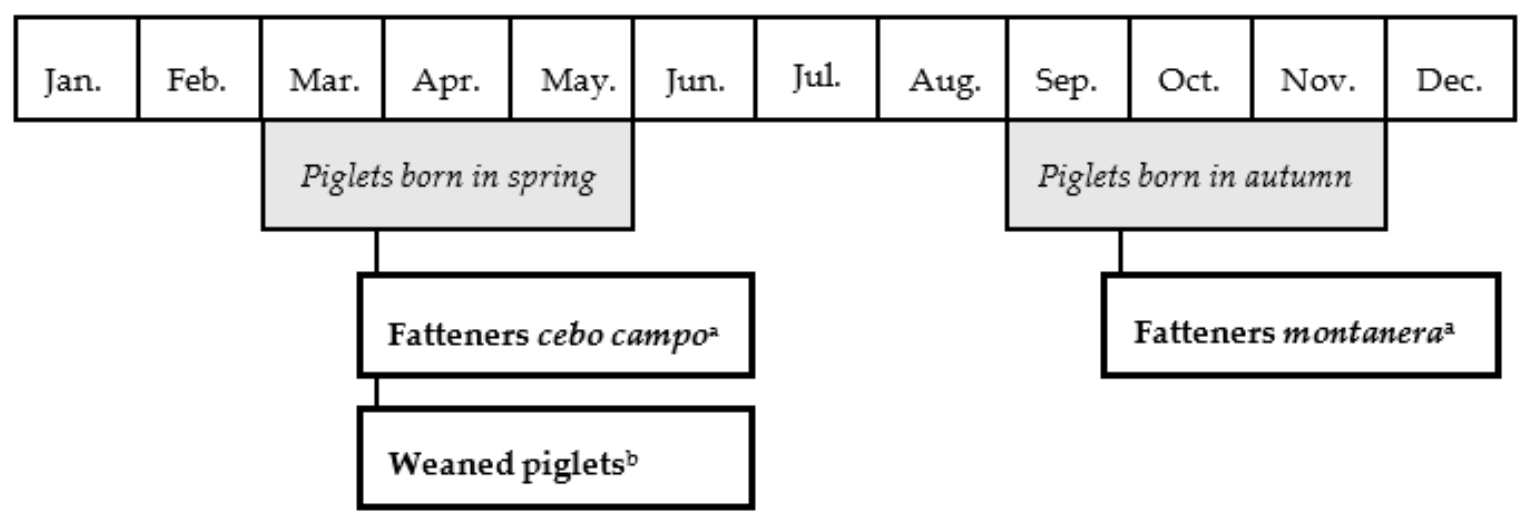

Figure 1. Calendar of traditional Iberian pig production with the extensive system. Destination of piglets according to the season of birth. ${ }^{a}$ Fattening the next year; ${ }^{b}$ Sale after weaning.

\subsection{Goal and Scope Definition}

The aim of this study was to conduct an environmental assessment of Iberian pig production systems in dehesa through LCA. As in most LCA studies [4,6,9-11], environmental impacts were estimated using models, emission factors, and databases previously developed, without direct measurement of emissions. The definition of the system boundaries was derived from Garcia-Launay et al. [24] and Espagnol and Demartini [13]. The perimeter of the analysis included inputs for crop production, concentrate feed production at the feed factory, animal production unit, and manure storage (Figure 2). The emissions that occur from nutrients' excretion were considered as well. The LCA considered both crop production in Spain and in other countries. Additionally, the assessment included processing feed ingredients such as soybean meal and sunflower oil and production of industrial products (fat, salt, dicalcium phosphate, calcium carbonate, L-lysine, L-threonine, L-valine and DL-methionine). The systems evaluated were farrow-to-finish systems that fatten all the piglets produced on the farm, in order to evaluate potential impacts of the system rather than impacts directly related to the orientation of the system (i.e., piglet production or production of fattening pigs). Therefore, the functional unit was one kilogram $(\mathrm{kg})$ of live weight $(\mathrm{LW})$ at farm gate (including $\mathrm{kg}$ of LW from fattening pigs and culled sows). 


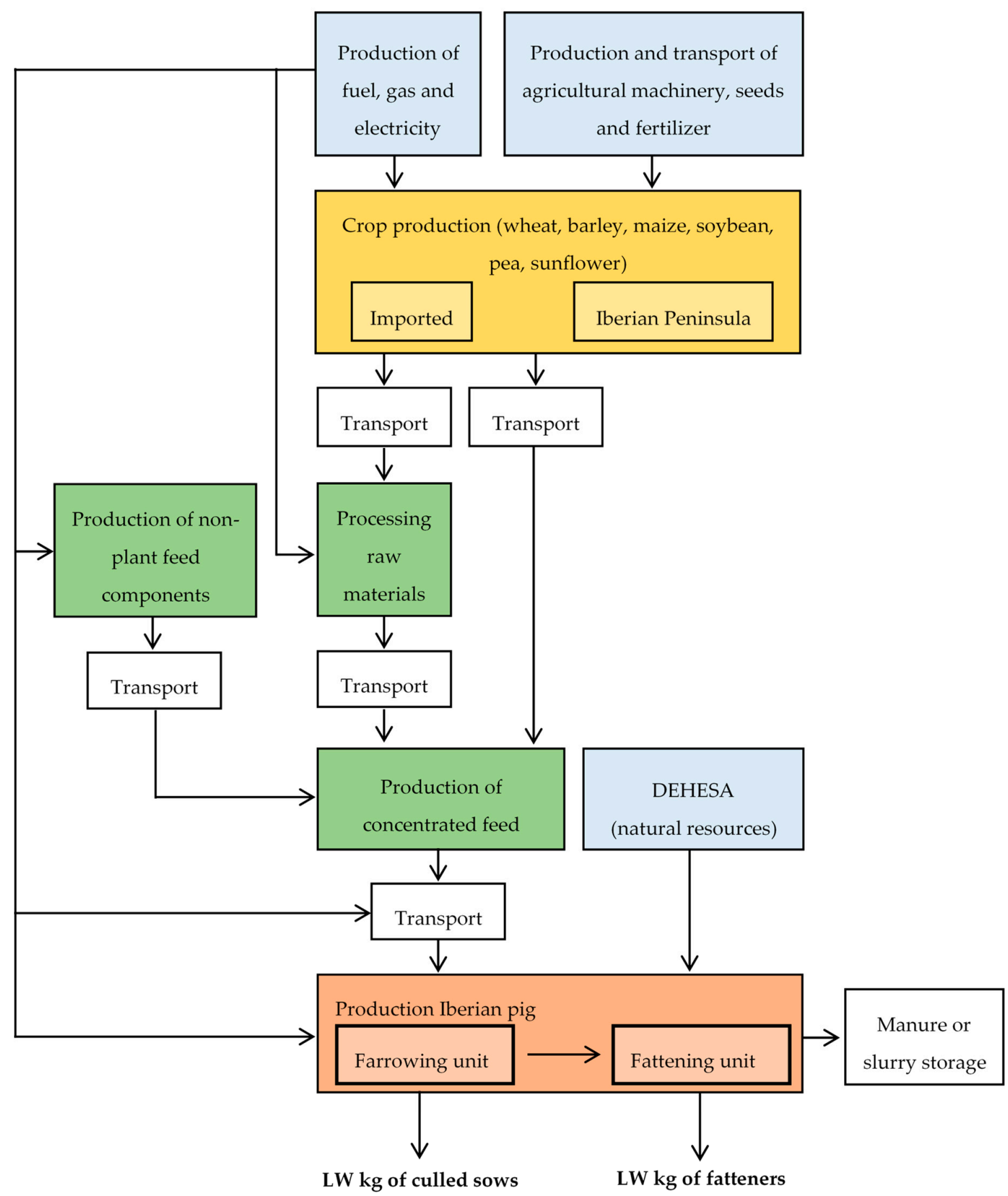

\begin{tabular}{|l|}
\hline Production of feed ingredients \\
\hline Production of compound feeds \\
\hline Iberian pig production \\
\hline Auxiliary inputs \\
\hline
\end{tabular}

Figure 2. Flow diagram for Iberian pig production in the Southwest of Spain, with the main processes for the production of crop inputs, crop production, production of feed ingredients and feeds and pig production. System boundaries include all sub-processes.

Energy use in the building and resources used for the construction of buildings were not included because all animals were raised outdoors except for sows kept in farrowing crates for a few farms $(n=10)$. Veterinary and cleaning products were also excluded because of lack of data from the surveys. 


\subsection{Allocation of Impacts}

When a production process generates multiple final co-products, it is necessary to allocate the process's impacts to the co-products. For the feed ingredients, allocation of impacts between co-products of cereals and between oils and meals were calculated using economic allocation according to Wilfart et al. [25]. The pig production itself generates fattened pigs of high market value and culled sows. Since the perimeter of the study was farm gate, we did not consider separately the relative products obtained from the different types of animals (fattened pigs and sows).

\subsection{Data Acquisition}

Data were collected from 33 farms ( 27 farms of montanera fatteners and 6 farms both montanera and cebo campo fatteners) through questionnaires (File S1). Information was collected about farm area (hectares of dehesa), number of breeding animals (sows, boars, gilts), number of animals produced and raised (piglets, growers and fatteners), reproductive performance (fertility, born alive and weaned), productive (age and weight at different stages, mortality rates) and management data (amount of feed distributed by type of animal per day, animal housing, etc.).

Farms included in the dataset used either the traditional (outdoor) or the conventional (indoor) farrowing system, and produced either pure Iberian or a part of crossbred pigs (50\% up to $75 \%$ Iberian).

Feed composition was collected from two feed companies for all physiological stages (sows gestation, sows lactation, piglets, weaners, growers and cebo campo fatteners). The main feed ingredients used were maize, barley, soft wheat, spring pea, soybean meal and sunflower oil (for more details see Table S1).

\subsection{Life Cycle Inventories for Feed Ingredients}

For feed ingredients related to crop production in Spain (soft wheat, maize, barley, spring pea and sunflower), life cycle inventories were derived from the ones constructed for the same crops in France by Wilfart et al. [25]. The yield and irrigation levels were modified according to data from the Spanish Ministry of Agriculture, Fishery and Food [26]. Amounts of mineral fertilizers were specified according to national recommendations [27], emissions of $\mathrm{N}-\mathrm{N}_{2} \mathrm{O}, \mathrm{N}-\mathrm{NO}_{3}$ and $\mathrm{NO}_{X}$ were calculated according to IPCC [28] and emission of $\mathrm{N}^{-\mathrm{NH}_{3}}$ was calculated according to SEI [29]. For soybean from Brazil, the life cycle inventory was taken from Wilfart et al. [25]. The electricity mix was modified for the Spanish electricity mix.

Distances for transportation of crops in Spain were calculated according to data from the Spanish Ministry of Agriculture, Fishery and Food [26] considering the distances from different regions of crop production in Spain (Andalucia, Aragon, Extremadura, Castilla-Leon, Castilla-La Mancha and Catalonia) to the Iberian pig region (Andalucia and Extremadura). The transport of feed ingredients to feed factory was considered in trucks with distances depending on the raw material (soft wheat at $344 \mathrm{~km}$, maize at $277 \mathrm{~km}$, barley at $375 \mathrm{~km}$, spring pea at $371 \mathrm{~km}$ and sunflower at $340 \mathrm{~km}$ ). Overseas transportation of soybean from Brazil to Europe was considered with soybean arrival at Lisbon harbour $(7500 \mathrm{~km})$ and transportation up to the Iberian pig region by trucks $(300 \mathrm{~km})$ for crushing.

\subsection{Life Cycle Inventories for Pig Production}

Life cycle inventories of feeds were constructed using the incorporation rates of each feedstuff found in the feed formulas provided by feed manufacturers. Transportation of feeds to the farms was added from data provided in the questionnaires $(58.60 \pm 72.89 \mathrm{~km})$. Feed intake per type of animal (gestating sow, lactating sow, grower, fattener) was calculated from information provided by a representative sample of Iberian pig farmers (Table 1). 
Table 1. Consumption of feed and natural resources according to type of animal ( $\mathrm{n}=33 \mathrm{farms}$ ).

\begin{tabular}{|c|c|c|c|}
\hline & Amount (Kg DM) & Minimum Value & Maximum Value \\
\hline \multicolumn{4}{|l|}{ Sow } \\
\hline Intake gestation feed (/year) & $455.9 \pm 167.1$ & 152.5 & 1068 \\
\hline Intake lactation feed (/year) & $264.7 \pm 86.28$ & 145.5 & 523.8 \\
\hline Grass intake a (/year) & $106.0 \pm 9.64$ & 71.27 & 121.4 \\
\hline \multicolumn{4}{|l|}{ Piglets-weaners } \\
\hline Feed intake (/piglet) & $2.91 \pm 1.37$ & 1.15 & 7.40 \\
\hline \multicolumn{4}{|l|}{ Growers } \\
\hline Feed intake (/pig) & $405.3 \pm 26.29$ & 360.0 & 468.0 \\
\hline 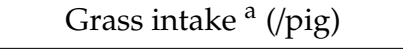 & $161.6 \pm 14.60$ & 126.8 & 186.8 \\
\hline \multicolumn{4}{|l|}{ Fatteners cebo campo } \\
\hline Feed intake (/pig) & $563.3 \pm 37.70$ & 428.1 & 608.3 \\
\hline Grass intake ${ }^{a}$ (/pig) & $34.85 \pm 3.18$ & 30.87 & 40.32 \\
\hline \multicolumn{4}{|l|}{ Fatteners montanera } \\
\hline Acorn intake ${ }^{b}$ (/pig) & $271.6 \pm 36.66$ & 217.5 & 348.0 \\
\hline Grass intake ${ }^{b}$ (/pig) & $46.82 \pm 6.32$ & 37.50 & 60.00 \\
\hline
\end{tabular}

${ }^{a}$ Grass intake is calculated according to literature and feed intake; ${ }^{\mathrm{b}}$ Acorn and grass intake in fatteners montanera

is calculated according to literature and fattening period (days); Dry Matter (DM).

Grass intake was calculated for sows outdoors [30]. Furthermore, grass intake of growers and fatteners cebo campo was estimated as a function of compound feed supply according to Monteiro et al. [15]. In both cases, the summer months were not included in the estimation of grass intake due to the null grass growth in the South West of the Iberian Peninsula during this season [31]. Similarly, acorn and grass intakes in fatteners montanera were estimated through literature data $[32,33]$ and average time spent in montanera indicated in questionnaires (Table 1).

Excretion of $\mathrm{N}, \mathrm{P}$, organic matter $(\mathrm{OM})$ and digested fibre were calculated by a mass-balance approach. N, P, OM and digested fibre intakes were calculated from feed, grass and acorn intakes and the nutrient contents of each one. Nutrient contents of feeds were provided by feed manufacturers. Nutrient contents of grass and acorn were consulted in literature [34-36]. For N and P, body retention was calculated according to Rigolot et al. [37] considering a lean percentage at slaughter of $30 \%$ from Freitas [38] for N, and according to Dourmad et al. [39] for P. Excretion was calculated for each physiological stage as the difference between nutrient intake and nutrient retention. Excretion of OM resulted from $\mathrm{OM}$ intake and digestibility of $\mathrm{OM}[34,40]$.

Emissions of $\mathrm{NH}_{3}, \mathrm{~N}_{2} \mathrm{O}, \mathrm{NO}_{X}, \mathrm{NO}_{3}$ and $\mathrm{CH}_{4}$ were calculated independently for gestating sows, lactating sows, weaners, growers, fatteners cebo campo and fatteners montanera. For animals kept outdoors, the emissions of $\mathrm{N}-\mathrm{NH}_{3}, \mathrm{~N}-\mathrm{N}_{2} \mathrm{O}, \mathrm{N}-\mathrm{NO}_{\mathrm{x}}$ and $\mathrm{N}-\mathrm{NO}_{3}$ were estimated according to the emission factors proposed by Basset-Mens et al. [7]. In addition, the emissions for indoor farrowing sows of $\mathrm{N}-\mathrm{NH}_{3}, \mathrm{~N}-\mathrm{N}_{2} \mathrm{O}, \mathrm{N}-\mathrm{NO}_{x}[41]$ and $\mathrm{N}-\mathrm{NO}_{3}$ [24] were calculated. Emissions of $\mathrm{CH}_{4}$ produced by enteric fermentation and manure management were estimated using Rigolot et al. [37,41] and IPCC [28].

\subsection{Characterization of the Impacts}

We calculated the impacts of Iberian pig production on climate change ILCD (CC, $\left.\mathrm{kg} \mathrm{CO}_{2} \mathrm{eq}\right)$, acidification ILCD (AC, molc $\mathrm{H}^{+}$eq), eutrophication CML baseline (EU, $\mathrm{kg} \mathrm{PO}_{4}{ }^{3-}$ eq), cumulative energy demand V1.8 non-renewable fossil+nuclear (CED, MJ) and land occupation CML non baseline $\left(\mathrm{LO}, \mathrm{m}^{2}\right.$.year). We used the International Reference Life Cycle Data System (ILCD) characterisation method recommended by the Joint Research Centre [42] for CC and AC, as well as the CML-IA characterisation method [43], which is the most popular in agricultural LCA. Energy demand was calculated according to the CED 1.08 method [43]. Analyses were performed with Simapro software 
(version 8.5.2.0, PRé Consultants, Amersfoort, The Netherlands) and the ecoinvent v3.1 database for background data [44] related to transportation and electricity production.

\section{Results}

\subsection{Iberian Pig Performance}

Productive indicators of Iberian pig farms varied greatly in the dataset. The average farm surface was $670 \pm 636.2$ ha where $529 \pm 437.8$ ha were used in the montanera period. Farms had an average of $34.4 \pm 25.23$ sows with 2 farrowing per year and $4 \pm 3.79$ boars. The number of weaned piglets was $6.17 \pm 0.74$ per litter with $11.6 \pm 4.40 \mathrm{~kg}$ of mean weight and $45.3 \pm 12.91$ days at weaning (depending on the management of farrowing). The average production per farm was $213.8 \pm 141.29$ fatteners montanera per year with $178.7 \pm 11.23 \mathrm{~kg}$ of mean slaughter weight and stocking density between 0.2 and 1.11 pigs/ha (in compliance with RD 4/2014 [23]) with an average density of 0.57 fatteners/ha. In farms with two types of fattening, 213 fatteners cebo campo, on average, were produced per year (for more details see Table S2).

\subsection{Impacts of Feed Ingredients and Complete Feed}

Environmental impacts of production and delivery at the feed factory of $1 \mathrm{t}$ of each feed ingredient is shown in Table 2. Maize had the lowest value for CC. Barley, spring pea and wheat showed intermediate values for this impact. Soybean meal from Brazil and sunflower oil had the highest values for $\mathrm{CC}$. For AC, the value of sunflower oil was twice higher compared to maize and the values of the other feed ingredients were lower. EU impact of sunflower oil obtained also the highest value (19.89 $\mathrm{kg} \mathrm{PO}_{4}{ }^{3-}$ eq) while other feed ingredients had values from 4 to $8 \mathrm{~kg} \mathrm{PO}_{4}{ }^{3-}$ eq. The highest values for CED were for sunflower oil, the intermediate values for spring peas and soybean meal and the lowest values for cereals (wheat, barley and maize). For LO, sunflower oil (17,667 $\mathrm{m}^{2}$.year) presented the highest values and the other feed ingredients had values lower than $10,000 \mathrm{~m}^{2} \cdot$ year/t. Sunflower oil was only used in fattening feed.

Table 2. Environmental impacts due to the production and delivery of $1 \mathrm{t}$ of each feed ingredient (at feed factory gate).

\begin{tabular}{cccccc}
\hline \multirow{2}{*}{ Feed Ingredients } & $\mathbf{C C}$ & $\mathbf{A C}$ & $\mathbf{E U}$ & $\mathbf{C E D}$ & $\mathbf{L O}$ \\
\cline { 2 - 6 } & $\mathbf{k g ~ C O} \mathbf{~} \mathbf{~ q}$ & $\mathbf{m o l c ~ H}^{+} \mathbf{~ e q}$ & $\mathbf{k g ~ P O}_{\mathbf{4}} \mathbf{3}^{\mathbf{2}} \mathbf{~ \mathbf { ~ q }}$ & $\mathbf{M J}$ & $\mathbf{m}^{\mathbf{2}} \cdot \mathbf{y e a r}$ \\
\hline Barley Spain & 633.8 & 7.92 & 6.41 & 4777 & 2917 \\
Maize Spain & 385.4 & 10.74 & 5.04 & 3281 & 907 \\
Soybean meal Brazil & 1124.4 & 7.18 & 4.84 & 7846 & 1529 \\
Spring pea Spain & 702.4 & 7.91 & 5.47 & 9635 & 9441 \\
Sunflower oil Spain & 1988.7 & 21.56 & 19.89 & 20,180 & 17,767 \\
Wheat Spain & 705.5 & 8.88 & 7.24 & 5213 & 2996 \\
\hline Climate Change (CC), Acidification (AC), Eutrophication (EU), Cumulative energy demand (CED), Land \\
occupation (LO).
\end{tabular}

Environmental impacts of the different compound feeds were similar within a same production stage (Table 3). In sow feeds, lactation feed showed higher values than gestating feed except for LO $\left(2303 \mathrm{~m}^{2} \cdot\right.$ year/t). Meanwhile, the impact values of transition feed were higher than the values in starter feed for weaned piglets except for AC (10.02 molc $\left.\mathrm{H}^{+} \mathrm{eq} / \mathrm{t}\right)$. For growing feed, AC and EU were higher (9.37 molc $\mathrm{H}^{+}$eq/t and $7.04 \mathrm{~kg} \mathrm{PO}_{4}{ }^{3-}$ eq/t, respectively) for company 1, and CC, CED and LO were higher $\left(808.5 \mathrm{~kg} \mathrm{CO}_{2} \mathrm{eq} / \mathrm{t}, 7321 \mathrm{MJ}\right.$ and $3060 \mathrm{~m}^{2}$.year/t, respectively) for company 2 . In the fattening stage, the compound feeds of company 2 (fattening 2 and quality fattening) showed higher values compared to feeds of company 1 (fattening 1 and final fattening). Quality fattening feed presented the highest values among the feeds provided for fatteners. 
Table 3. Environmental impacts due to the production at the feed factory gate of $1 \mathrm{t}$ of each compound feed.

\begin{tabular}{|c|c|c|c|c|c|}
\hline \multirow{2}{*}{ Compound Feed } & $\mathrm{CC}$ & AC & EU & CED & LO \\
\hline & $\mathrm{kg} \mathrm{CO} 2 \mathrm{eq}$ & molc $\mathrm{H}^{+}$eq & $\mathrm{kg} \mathrm{PO}_{4}{ }^{3-}$ eq & MJ & $\mathrm{m}^{2} \cdot$ year \\
\hline \multicolumn{6}{|l|}{ Sow } \\
\hline Gestating & 764.3 & 9.06 & 6.83 & 6682 & 2598 \\
\hline Lactating & 805.0 & 9.55 & 6.88 & 7087 & 2303 \\
\hline \multicolumn{6}{|l|}{ Piglets-weaners } \\
\hline Starter & 768.1 & 10.25 & 7.20 & 7296 & 1886 \\
\hline Transition & 812.2 & 10.02 & 8.07 & 7634 & 2187 \\
\hline \multicolumn{6}{|l|}{ Growers } \\
\hline Growing $1^{\mathrm{a}}$ & 773.0 & 9.37 & 7.04 & 6835 & 2396 \\
\hline Growing2 ${ }^{a}$ & 808.5 & 8.98 & 6.85 & 7321 & 3060 \\
\hline \multicolumn{6}{|l|}{ Fatteners cebo campo } \\
\hline Fattening $1^{a}$ & 695.5 & 9.55 & 6.47 & 6191 & 2396 \\
\hline Fattening2 $^{\mathrm{a}}$ & 774.9 & 9.58 & 7.07 & 7420 & 3386 \\
\hline Final Fattening & 686.2 & 9.66 & 6.58 & 6143 & 2445 \\
\hline Quality Fattening & 818.9 & 9.88 & 7.66 & 7997 & 4486 \\
\hline
\end{tabular}

\subsection{Impacts of Iberian Pig Production in Dehesa}

Table 4 shows the average environmental impacts for Iberian pig production, for farms finishing pigs in montanera, and for farms with pigs finished in either montanera or cebo campo. Farms with fatteners from montanera and fatteners from cebo campo exhibited values of CC (4.36 $\left.\mathrm{kg} \mathrm{CO}_{2}\right), \mathrm{AC}$ $\left(0.110\right.$ molc $\left.\mathrm{H}^{+}\right)$, EU $\left(0.057 \mathrm{~kg} \mathrm{PO}_{4}{ }^{-3}\right)$ and CED (28.6 MJ) per $\mathrm{kg}$ of pig 22, 17, 95 and $28 \%$ higher, respectively, than farms with fatteners only in montanera. For LO, however, values per $\mathrm{kg}$ of pig were higher for farms using only montanera fattening $\left(43.0 \mathrm{~m}^{2} \cdot\right.$ year $)$ than for farms using both montanera and cebo campo ( $31.6 \mathrm{~m}^{2}$.year).

Table 4. Environmental impacts of pig production in the traditional Iberian system, obtained from the whole dataset (33 farms).

\begin{tabular}{|c|c|c|c|}
\hline \multicolumn{4}{|c|}{ Impacts Per kg of Live Pig at Farm Gate in Farms with montanera (27 Farms) } \\
\hline Environmental Impacts & Mean \pm Standard Deviation & Minimum Value & Maximum Value \\
\hline Climate change ( $\mathrm{kg} \mathrm{CO} 2 \mathrm{eq})$ & $3.40 \pm 0.223$ & 2.88 & 3.84 \\
\hline Acidification (molc $\mathrm{H}+\mathrm{eq}$ ) & $0.091 \pm 0.004$ & 0.08 & 0.10 \\
\hline Eutrophication $\left(\mathrm{kg} \mathrm{PO}_{4}{ }^{3-} \mathrm{eq}\right)$ & $0.046 \pm 0.002$ & 0.04 & 0.05 \\
\hline Non-renewable Energy (MJ) & $20.65 \pm 1.698$ & 16.78 & 23.36 \\
\hline Land Occupation $\left(\mathrm{m}^{2} \cdot\right.$ year $)$ & $43.01 \pm 22.807$ & 16.46 & 126.0 \\
\hline \multicolumn{4}{|c|}{ Impacts Per Kg of Live Pig at Farm Gate in Farms with montanera and cebo campo (6 Farms) } \\
\hline Environmental Impacts & Mean \pm Standard Deviation & Minimum Value & Maximum Value \\
\hline Climate change $\left(\mathrm{kg} \mathrm{CO}_{2} \mathrm{eq}\right)$ & $4.36 \pm 0.428$ & 3.90 & 5.16 \\
\hline Acidification (molc $\mathrm{H}+\mathrm{eq}$ ) & $0.110 \pm 0.010$ & 0.10 & 0.13 \\
\hline Eutrophication $\left(\mathrm{kg} \mathrm{PO}_{4}{ }^{3-} \mathrm{eq}\right)$ & $0.057 \pm 0.005$ & 0.05 & 0.07 \\
\hline Non-renewable Energy (MJ) & $28.57 \pm 3.523$ & 24.09 & 34.81 \\
\hline Land Occupation $\left(\mathrm{m}^{2} \cdot\right.$ year $)$ & $31.60 \pm 6.662$ & 24.17 & 42.65 \\
\hline
\end{tabular}




\subsection{Contribution of Processes to Impacts}

Figure 3 a shows the contribution of the different stages of Iberian pig production to environmental impacts in the farms with animals fattened only in montanera. Growing stage showed the greatest contribution to CC, AC, EU and CED whereas the finishing period contributed to LO the most. The impacts of the growing period and of the production of piglets were caused by both on-farm emissions and feed production, whereas feed production for finishing pigs did not contribute to the impacts since no feed was supplied for fattening in montanera. Contribution of transport was low in all environmental impacts (between 0 and $2 \%$ ).

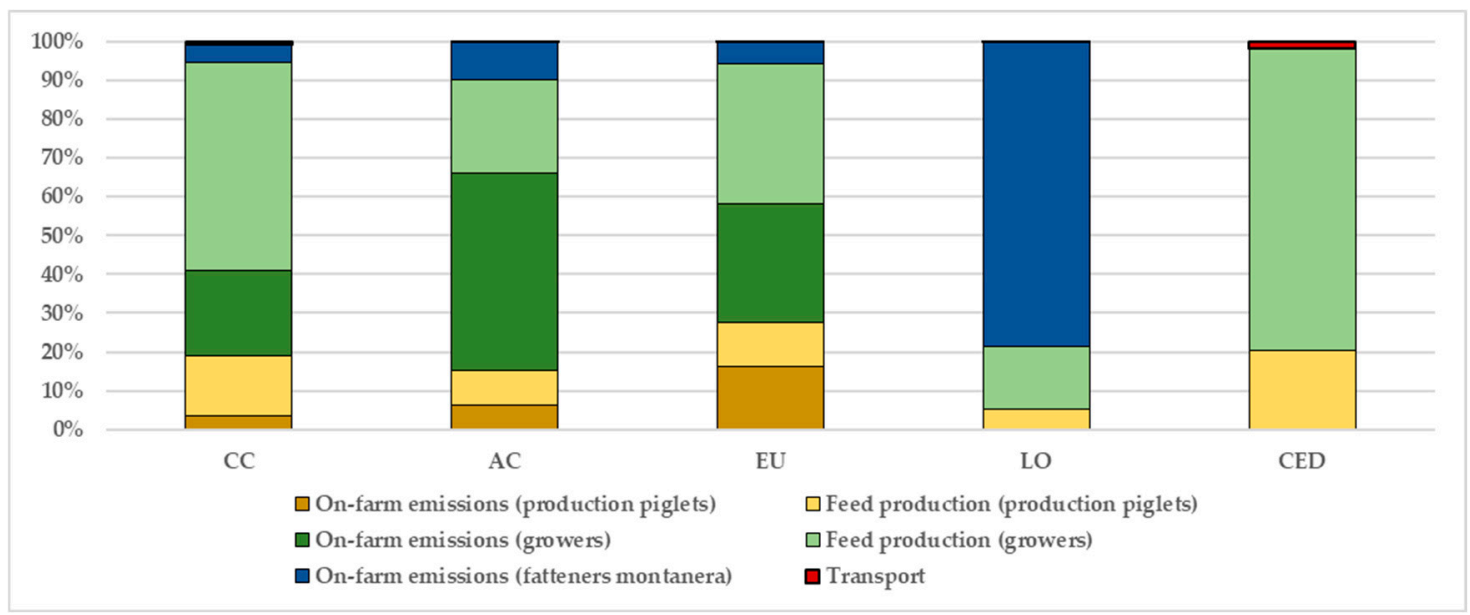

(a)

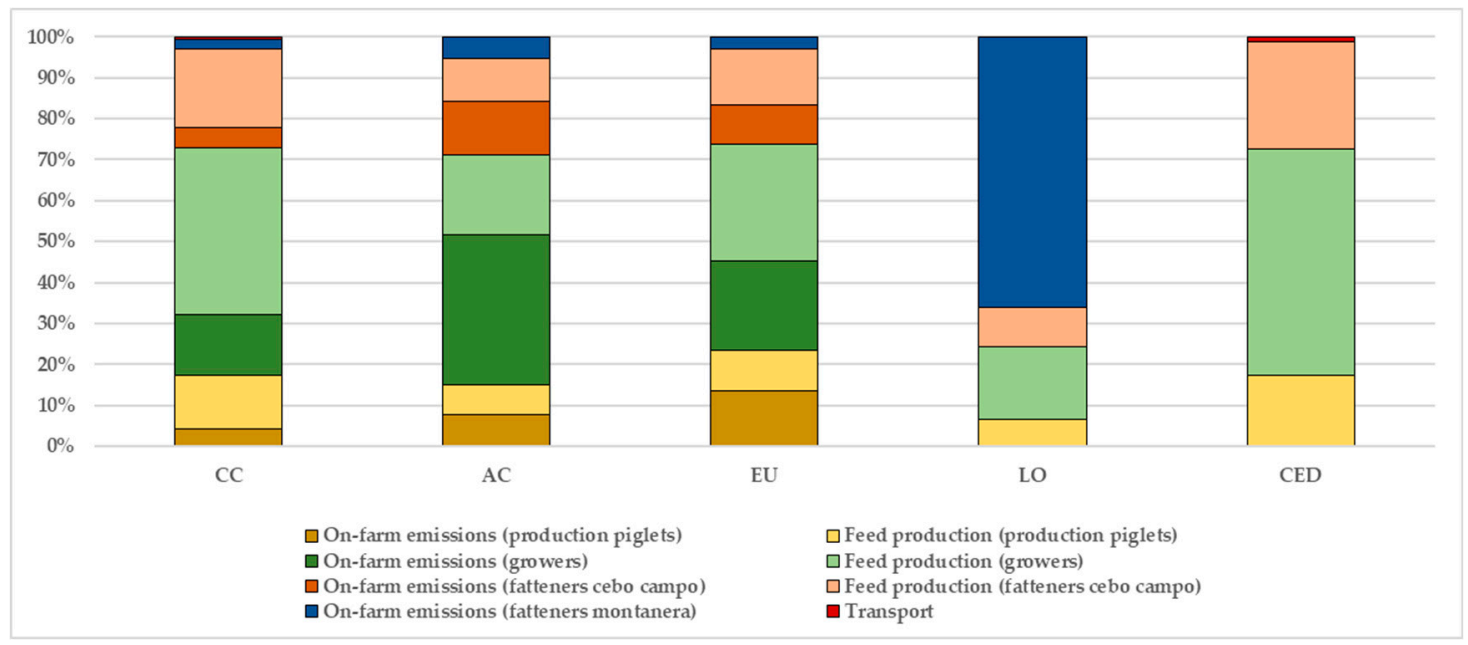

(b)

Figure 3. Mean contribution of physiological stages (production of piglets, growers, fatteners) and transport to climate change (CC), acidification (AC), eutrophication (EU), cumulative energy demand (CED) and land occupation (LO) impacts expressed per $\mathrm{kg}$ of pig live weight at farm gate. (a) Farms fattening all pigs in montanera (27 farms) and (b) Farms fattening some pigs in montanera and some pigs in cebo campo (6 farms).

The growing stage was the greatest contributor to CC (75\%) followed by the production of piglets $(19 \%)$. Feed production was the main contributor to CC of these production stages (53\% in growers and $15 \%$ in production of piglets). Fatteners' contribution to CC (5\%) was only associated with on-farm emissions. Growing period was responsible for $75 \%$ of the AC potential impact, mainly with on-farm 
emissions (51\%). Piglets production contributed to $15 \%$ of AC ( $9 \%$ feed production and $6 \%$ on-farm emissions). On-farm emissions associated with finishing pigs accounted for $10 \%$ of AC. EU followed the same ranking of production stages as previous impacts. First, growers contributed to $66 \%$ and secondly, production piglets contributed to $27 \%$ of impacts. In this case, feed production and on-farms emissions had a similar contribution to the EU, in the growing stage ( $36 \%$ and $30 \%$, respectively) and in the production of piglets ( $16 \%$ and $11 \%$, respectively). Finishing pigs showed a low contribution $(6 \%)$ to EU, from on-farm emissions. CED impact resulted only from feed production and transport, $78 \%$ due to the growing stage and $20 \%$ due to the production of piglets. LO impact was mainly determined by fatteners in montanera $(79 \%)$, followed by growers and production piglets $(16 \%$ and $5 \%$, respectively).

When the farms fatten animals in montanera and cebo campo the contribution of the different stages to environmental impacts had a different pattern (Figure 3b). In this farm type, contribution of transport was also low in all environmental impacts (between 0 and 1 per cent). Main production stages contributing to impacts (CC, AC, EU and CED) were growers, fatteners in cebo campo, production piglets and fatteners in montanera. The main production stage contributing to LO impact was fatteners in montanera.

For CC, AC and EU impacts, growing pigs resulted in more than half of the emissions (55\%, $56 \%$ and $50 \%$, respectively). Fatteners in cebo campo caused about a quarter of emissions ( $24 \%, 23 \%$ and $23 \%$, one by one). The production of piglets had a lower contribution to these impacts $(17 \%, 15 \%$ and $23 \%$, respectively). Feed production was less important than on-farm emissions in AC. Fatteners in montanera only produced on-farm emissions ( $2 \%$ in CC, $5 \%$ in AC and $3 \%$ in EU). CED impact was determined by the production of feed for growers, fatteners cebo campo and the production of piglets $(55 \%, 26 \%$ and $17 \%$, respectively). Finally, LO impact was mainly determined by fatteners in montanera $(66 \%)$, followed by growers, fatteners cebo campo and production of piglets $(18 \%, 9 \%$ and $7 \%$, respectively).

\subsection{Relationship Between Type of Fattening System and Environmental Impacts}

Six farms of the dataset produced two types of fatteners (montanera and cebo campo). Figure 4 shows the relationships between the ratio of production from cebo campo ( $\mathrm{kg}$ of $\mathrm{LW}$ ) to production from montanera (kg of LW) (ProdRatio) and the different environmental impacts. The higher the ratio, the greater the impact was, for CC, AC, EU and CED. The relationship between LO impact and ProdRatio was less clear $\left(R^{2}=0.57\right)$ since the area dedicated to outdoor pigs in each farm was very variable.

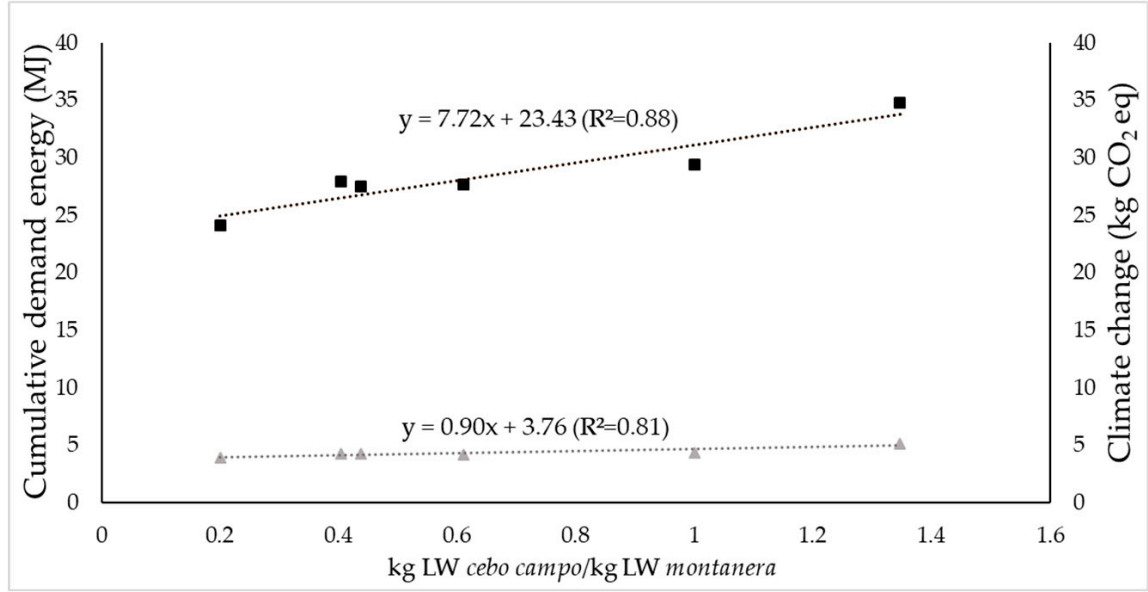

(a)

Figure 4. Cont. 


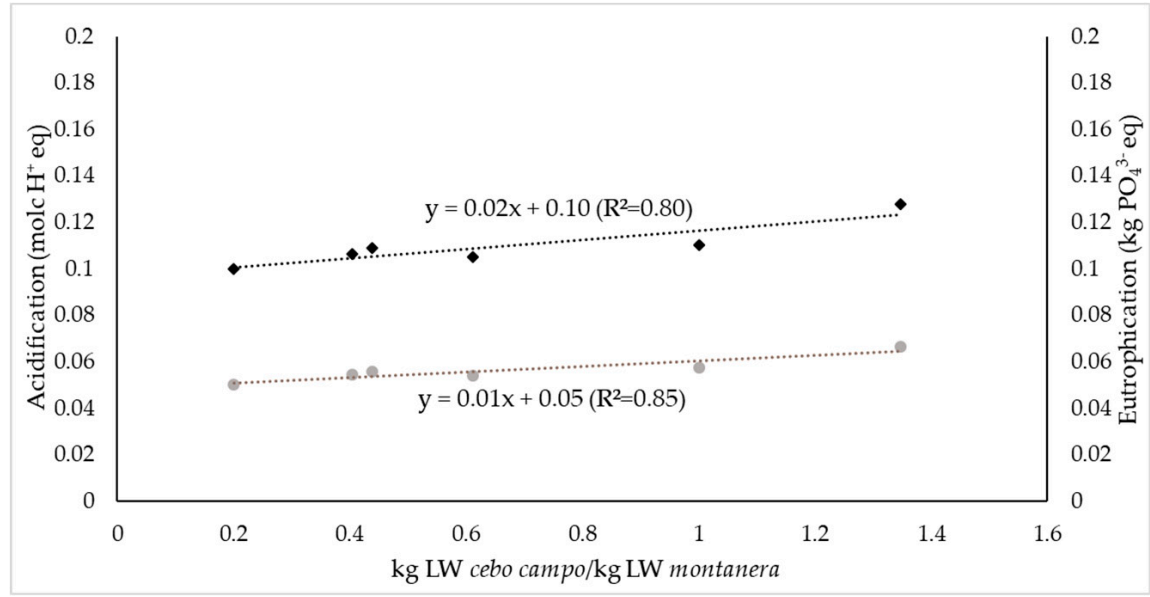

(b)

Figure 4. Potential environmental impacts of pig production. (a) acidification ( $)$ and eutrophication $(\odot),(\mathbf{b})$ cumulative demand energy $(\boldsymbol{\square})$ and climate change $(\Delta)$ according to the type of fattening expressed as the ratio between the production made in cebo campo system and the production made in the montanera system. The kilogram of live weight (LW) is plotted on the x-axis.

\section{Discussion}

\subsection{Methodological Challenge: Accounting for the Consumption of Natural Resources}

The present study is one of the first to include the emissions resulting from the consumption of natural resources in the assessment. In traditional Iberian systems, the excretion of nutrients associated with the consumption of natural resources contributes to CC, AC, EU and LO impacts. This contribution applies to the different outdoor stages. For CC, AC and EU the contribution of natural resources corresponded to on-farm emissions of fatteners montanera and to one part of the on-farm emissions of the other outdoor stages (sows, growers and fatteners cebo campo). For LO, the contribution of natural resources was associated to both the surface of dehesa occupied by fatteners montanera during approximately 100 days and the surface of grasslands used for the other outdoor stages (sows, growers and fatteners cebo campo).

In systems depending on the consumption of natural resources by outdoor pigs, like the traditional Iberian production system, it appeared relevant to consider the acorn and grass intakes in the life cycle perimeter. Indeed, the contribution of fatteners montanera reached at least $5 \%$ of CC, $6 \%$ of $\mathrm{EU}$ and $10 \%$ of AC (Figure 3a). The final contribution of the consumption of natural resources was higher because there was also contribution from the other outdoor production stages. The fatteners montanera accounted for at least $79 \%$ of LO (Figure 3a) because of the large surfaces used (between 0.2 and 1.11 pigs per hectare).

When Iberian farms have both montanera and cebo campo systems, the contribution of natural resources to impacts decreases due to greater dependence on compound feed. In these farms, the contribution of fatteners montanera (depended on natural resources) was reduced to half for CC, AC and EU impacts in comparison with farms with only fatteners montanera but remained predominant in LO impact (Figure 3b).

Depending on the type of natural resource consumed by pigs during each productive stage, the emissions may vary. Consumption of acorns should result in low emissions due to their low $\mathrm{N}$ and digestible fibre content and high organic matter (OM) digestibility [34]. Consumption of grass should have higher contribution to emissions, because of its higher digestible fibre and crude protein content, i.e., $22.20 \%$ of $\mathrm{CP}$ compared to $5.88 \%$ of $\mathrm{CP}$ for acorn [34]. Therefore, when animals consume grass, higher $\mathrm{N}$ excretion and emissions of $\mathrm{NH}_{3}, \mathrm{NO}_{X}$ and $\mathrm{NO}_{3}$ are expected. Additionally, because 
of its higher digestible fibre content, higher enteric $\mathrm{CH}_{4}$ emissions are expected [37,41]. Grazing by the animals is related to enteric fermentation [3]. Therefore, it was relevant to account for natural resources in the LCA of the Iberian traditional pig production system, since these resources are consumed during all production stages. Indeed, although dehesa can be considered a natural ecosystem without intervention from farmers, $\mathrm{N}$ and $\mathrm{OM}$ ingested from acorns and grass are provided to the environment in a form (urine and faeces) that is expected to result in higher volatilization than natural degradation on the ground. Therefore, we have recommended the inclusion of emissions derived from the consumption of natural resources in the perimeter of an LCA when dealing with systems with outdoor pigs, because it contributes to about $10 \%$ of CC, AC and EU.

If the intake of natural resources had not been included in the assessment (Table 5), no emissions of $\mathrm{NH}_{3}, \mathrm{~N}_{2} \mathrm{O}, \mathrm{NO}_{\mathrm{X}}, \mathrm{NO}_{3}, \mathrm{CH}_{4}$ would have been considered in fatteners during montanera. Additionally, emissions estimated of $\mathrm{NH}_{3}, \mathrm{~N}_{2} \mathrm{O}, \mathrm{NO}_{\mathrm{X}}, \mathrm{NO}_{3}$ would have decreased by $40 \%$ in growing pigs. In the case of fatteners cebo campo, the decrease in these emissions would have represented only $10 \%$, due to a higher intake of compound feed per day and a decrease in grass intake [15]. Furthermore, the emissions calculated of enteric $\mathrm{CH}_{4}$ and $\mathrm{CH}_{4}$ from the faeces and urine deposited would have also decreased in these production stages. The reduction of emissions in sows was not calculated since lactating sows have access to natural resources only in some farms (farrowing in huts). Consumption of natural resources was not considered for piglets, because of the post-natal development of the digestive system [45].

Table 5. Average emissions of nitrogen compounds and methane per pig, when accounting or not for excretion of nutrients resulting from the consumption of natural resources (grass and acorn).

\begin{tabular}{|c|c|c|c|c|c|c|}
\hline Production Stage & $\mathrm{NH}_{3}(\mathrm{Kg})$ & $\mathrm{N}_{2} \mathrm{O}(\mathrm{Kg})$ & NOx (Kg) & $\mathrm{NO}_{3}(\mathrm{Kg})$ & $\mathrm{CH}_{4} \mathrm{e}(\mathrm{Kg})$ & $\mathrm{CH}_{4} \mathrm{~m}(\mathrm{Kg})$ \\
\hline Growers & & & & & & \\
\hline NR considered & 2.62 & 0.283 & 0.092 & 22.30 & 1.478 & 0.332 \\
\hline NR not considered & 1.56 & 0.168 & 0.055 & 13.30 & 0.407 & 0.276 \\
\hline Emission reduction ${ }^{\mathrm{a}}(\%)$ & \multicolumn{4}{|c|}{40.37} & 72.49 & 16.86 \\
\hline \multicolumn{7}{|l|}{ Fatteners cebo campo } \\
\hline NR considered & 2.15 & 0.232 & 0.076 & 18.30 & 0.728 & 0.438 \\
\hline NR not considered & 1.94 & 0.209 & 0.068 & 16.47 & 0.508 & 0.427 \\
\hline Emission reduction ${ }^{a}(\%)$ & \multicolumn{4}{|c|}{10.00} & 30.28 & 2.65 \\
\hline \multicolumn{7}{|l|}{ Fatteners montanera } \\
\hline NR considered & 0.523 & 0.056 & 0.018 & 4.45 & 0.403 & 0.111 \\
\hline NR not considered & 0.000 & 0.000 & 0.000 & 0.00 & 0.000 & 0.000 \\
\hline Emission reduction ${ }^{\mathrm{a}}(\%)$ & \multicolumn{6}{|c|}{100.0} \\
\hline
\end{tabular}

${ }^{a}$ Emission reduction if natural resources are not included in the LCA perimeter; Natural Resources (NR), $\mathrm{CH}_{4}$ enteric $\left(\mathrm{CH}_{4} \mathrm{e}\right), \mathrm{CH}_{4}$ from manure $\left(\mathrm{CH}_{4} \mathrm{~m}\right)$.

\subsection{Environmental Impacts of Iberian Traditional Pig Production Systems vs. Other Pig Production Systems}

This study provided the first life cycle assessment of traditional Iberian pig production. Several authors estimated environmental impacts of pig production (Table 6). Conventional, organic and traditional systems have already been assessed through LCA [4]. Therefore, in this section we compare the environmental impacts of pig production in traditional Iberian systems with conventional, organic and traditional systems investigated in the literature. We also provide insights on the potential mitigation of impacts through the consumption of natural resources by free-ranging pigs.

In Iberian pig production systems, CC, AC, EU and LO values (Table 4) are higher than those obtained in conventional systems (Table 6). Indeed, conventional systems are commonly based on high productivity, while extensive systems promote carcass quality over quantity [46]. CC in conventional systems ranges between 2.22 and $2.89 \mathrm{~kg} \mathrm{CO}_{2}$ eq [9,24,47-51] while EU ranges between 0.014 and $0.023 \mathrm{~kg} \mathrm{PO}_{4}{ }^{3-}$ eq $[9,24,47,49,50]$ and $\mathrm{AC}$ between 0.058 and 0.063 molc $\mathrm{H}^{+}$[52]. Iberian pig systems had higher $\mathrm{CC}, \mathrm{AC}$ and EU impacts than conventional systems, in both farms with only fatteners montanera (3.40 $\mathrm{kg} \mathrm{CO}_{2}, 0.091$ molc $\mathrm{H}^{+}$and $0.046 \mathrm{~kg} \mathrm{PO}_{4}{ }^{3-}$ eq, respectively) and farms with fatteners 
montanera and cebo campo (4.36 $\mathrm{kg} \mathrm{CO}_{2}, 0.110$ molc $\mathrm{H}^{+}$and $0.057 \mathrm{~kg} \mathrm{PO}_{4}{ }^{3-}$ eq, respectively). This was due to the lower feed efficiency of the traditional breeds [53]. LO in this study (31.60 and $43.01 \mathrm{~m}^{2}$.year) was lower than $\mathrm{LO}$ in a conventional system reported in the literature $[9,47,51]$. It resulted from land surfaces required for fatteners montanera [23]. CED in Iberian farms with fatteners montanera and cebo campo (31.60 MJ) was higher than CED in conventional production, due to large quantities of compound feed distributed during growing and finishing periods to fatteners of cebo campo. However, CED in Iberian farms using only montanera $(20.65 \mathrm{MJ})$ is approximately equivalent to the highest values (16.22 and 20.80 MJ) in conventional systems [9,24]. Environmental impacts of Iberian pig production in traditional systems are reduced when using only the montanera system for finishing (vs. cebo campo). Therefore, relying on the ability of Iberian pigs to consume acorns and to valorise them with compensatory growth allows these systems to reach environmental impacts close to those of conventional systems despite lower growth potential.

Table 6. Results of CC, EU, CED and LO of conventional, organic and traditional systems from recent LCA studies.

\begin{tabular}{|c|c|c|c|c|c|c|c|}
\hline \multirow{2}{*}{ Reference } & \multirow{2}{*}{ Country } & \multirow{2}{*}{ System } & \multirow{2}{*}{ Mgmt } & $\mathrm{CC}$ & EU & CED & LO \\
\hline & & & & $\left(\mathrm{kg} \mathrm{CO} \mathrm{Cl}_{2}\right.$ eq) & $\left(\mathrm{kg} \mathrm{PO}_{4}{ }^{3-}\right.$ eq) & (MJ) & $\left(\mathrm{m}^{2} \cdot\right.$ year $)$ \\
\hline Basset-Mens et al. (2005) & FR & $\mathrm{C}$ & I & 2.30 & 0.021 & 15.90 & 5.43 \\
\hline Pelletier et al. (2010) & US & $\mathrm{C}$ & I & 2.47 & 0.016 & 9.70 & \\
\hline Garcia-Launay et al. (2014) & FR & $\mathrm{C}$ & I & $2.22-2.77$ & $0.0165-0.023$ & $18.10-20.80$ & \\
\hline Dourmad et al. (2014) & UE & $\mathrm{C}$ & I & 2.25 & 0.019 & 16.22 & 4.13 \\
\hline González-García et al. (2015) & PT & $\mathrm{C}$ & I & 2.61 & & 14.30 & \\
\hline Monteiro et al. (2016) & FR & $\mathrm{C}$ & I & $2.28-2.89$ & & $11.70-14.40$ & $3.89-4.05$ \\
\hline Mackenzie et al. (2016) & CA & $\mathrm{C}$ & I & $2.24-2.32$ & 0.014 & 15.80 & \\
\hline Basset-Mens et al. (2005) & FR & $\mathrm{O}$ & $\mathrm{I} / \mathrm{O}$ & 3.97 & 0.022 & 22.20 & 9.87 \\
\hline Halberg et al. (2010) & DK & $\mathrm{O}$ & $\mathrm{I}$ & 2.92 & & & 6.90 \\
\hline Halberg et al. (2010) & DK & $\mathrm{O}$ & $\mathrm{O}$ & 3.32 & & & 9.20 \\
\hline Halberg et al. (2010) & DK & $\mathrm{O}$ & $\mathrm{I} / \mathrm{O}$ & 2.83 & & & 8.50 \\
\hline Dourmad et al. (2014) & UE & $\mathrm{O}$ & $\mathrm{O}$ & 2.43 & 0.016 & 18.08 & 9.14 \\
\hline Rudolph et al. (2018) & UE & $\mathrm{O}$ & I & 2.20 & 0.022 & & \\
\hline Rudolph et al. (2018) & UE & $\mathrm{O}$ & $\mathrm{I} / \mathrm{O}$ & 2.21 & 0.020 & & \\
\hline Rudolph et al. (2018) & UE & $\mathrm{O}$ & $\mathrm{O}$ & 2.21 & 0.029 & & \\
\hline Dourmad et al. (2014) & UE & $\mathrm{T}$ & $\mathrm{I} / \mathrm{O}$ & 3.47 & 0.034 & 24.28 & 10.58 \\
\hline Espagnol \& Demartini (2014) & FR & $\mathrm{T}$ & $\mathrm{O}$ & 4.09 & 0.054 & 20.20 & 6.43 \\
\hline Espagnol \& Demartini (2014) & FR & $\mathrm{T}$ & $\mathrm{O}$ & 3.03 & 0.053 & 15.80 & 7.83 \\
\hline Espagnol \& Demartini (2014) & FR & $\mathrm{T}$ & $\mathrm{O}^{*}$ & 1.47 & 0.012 & 7.70 & 2.14 \\
\hline Pirlo et al. (2016) & IT & $\mathrm{T}$ & I & 3.30 & 0.031 & & \\
\hline Bava et al. (2017) & IT & $\mathrm{T}$ & $\mathrm{I}$ & 4.25 & 0.026 & 23.50 & 8.39 \\
\hline Garcia-Launay et al. (2018) & FR & $\mathrm{T}$ & $\mathrm{O}$ & 4.54 & 0.047 & 19.90 & 22.70 \\
\hline Monteiro et al. (2019) & SI & $\mathrm{T}$ & $\mathrm{I} / \mathrm{O}$ & 6.94 & 0.038 & 35.60 & 10.40 \\
\hline Monteiro et al. (2019) & IT & $\mathrm{T}$ & $\mathrm{I} / \mathrm{O}$ & 9.35 & 0.036 & 33.70 & 7.55 \\
\hline Monteiro et al. (2019) & FR & $\mathrm{T}$ & $\mathrm{I} / \mathrm{O}$ & 5.07 & 0.047 & 24.70 & 11.00 \\
\hline
\end{tabular}

Mgmt: Management; C: Conventional; O: Organic; T: Traditional; I: Indoor; O: Outdoor; * Dependent exclusively on natural resources in fattening.

Iberian systems have CC, EU and LO impacts (Table 4) rather greater than organic systems (Table 6), since these systems exhibit CC values between 2.20 and $2.92 \mathrm{~kg} \mathrm{CO}_{2}{ }^{-}$eq [8-10], EU values from 0.016 to $0.029 \mathrm{~kg} \mathrm{PO}_{4}{ }^{3-}$ eq $[8,9,47]$ and $\mathrm{LO}$ values from 6.9 to $9.87 \mathrm{~m}^{2}$.year $[8,9,47]$. Halberg et al. [8] additionally assessed a free range organic system, and calculated a CC value ( $3.32 \mathrm{~kg} \mathrm{CO}_{2}$ eq) close to those of Iberian farms with fatteners montanera ( $3.40 \mathrm{~kg} \mathrm{CO}_{2}{ }^{-}$eq). A long productive cycle with high slaughter weight and a low feed efficiency $[17,53]$ were the main causes of higher impacts in Iberian systems than in organic systems. In contrast, the CED value obtained (Table 4 ) in this study was near the CED value in organic systems (18.08 MJ [9]) when finishing pigs were fed only with natural resources. In addition, Basset-Mens et al. [47] obtained higher CC and CED values in the organic system than Iberian farms for fatteners montanera but lower than Iberian farms with fatteners montanera and cebo campo. 
In recent years, environmental impacts of traditional pig production were estimated by several authors [9,11-15]. The values (Table 6) vary greatly due to different farm managements and breeds. For this reason, CC, EU and CED impacts in Iberian systems are within the range of values found in the literature (3.03 to $9.35 \mathrm{~kg} \mathrm{CO}^{2}$ eq, 0.026 to $0.054 \mathrm{~kg} \mathrm{PO}_{4}{ }^{3-}$ eq and 14.40 and $35.60 \mathrm{MJ}$, respectively). Traditional indoor systems had lower EU values, while traditional outdoor systems like the Iberian one obtained the highest EU values. Traditional mixed systems (indoor and outdoor) obtained EU intermediate values. Indeed, the higher efficiency of intensive systems needs less inputs per functional unit than extensive systems [3]. Finally, LO values in Iberian systems are higher than $\mathrm{LO}$ values in other traditional systems (6.43 to $22.70 \mathrm{~m}^{2}$.year) primarily due to the use of a large surface in the fattening period. A traditional Corsican system [13] obtained the lowest CC, EU, CED and LO values $\left(1.47 \mathrm{~kg} \mathrm{CO}^{2} \mathrm{eq}, 0.012 \mathrm{~kg} \mathrm{PO}_{4}{ }^{3-}\right.$ eq, $7.70 \mathrm{MJ}$ and $2.14 \mathrm{~m}^{2} \cdot$ year, respectively) of the assessed traditional systems.

Consumption of natural resources (chestnuts, acorns and grass) in LCA was only previously considered by Monteiro et al. [15] who calculated the emissions from grazing in different systems using local breeds. Espagnol and Demartini [13] did not considered the natural resources in the LCA perimeter when assessing the environmental impacts of Corsican pig production systems. Environmental impacts obtained in traditional Iberian systems (Table 4) were in line with the values obtained with other European local breeds [15]. However, values obtained in this study were higher than the ones obtained by Espagnol and Demartini [13] for the Corsican system.

One of the causes for high impacts in Iberian pig systems is that Iberian pig protein deposition is potentially lower than in modern highly selected breeds [53]. Additionally, the animals reared in free-range use the calories to cover energy requirements for maintenance and the energetic cost of grazing [32]. As a result, the feed efficiency was also lower in this system. The use of natural resources from the dehesa [17] together with the ability of Iberian pigs to shell acorns [54] may compensate the lower feed efficiency when animals are fed with natural resources. Indeed, when the ratio of production from cebo campo to production from montanera increased, the different environmental impacts increased and vice versa (Figure 4). This was due to greater use of compound feed in cebo campo. Furthermore, a low distribution of compound feed per day during the growing period in Iberian pigs causes compensatory growth in montanera, which increases feed efficiency and contributes to reduced $\mathrm{N}$ excretion and environmental impacts. According to Stanley et al. [55], the management of fatteners montanera (extensive fattening based on natural resources in a large area with rotational management) provides environmental benefits (such as soil $C$ sequestration and other ecosystem services) and lower environmental impacts per kilogram carcass weight. Therefore, the montanera system generates lower total meat production, although it is produced with greater environmental benefits than the cebo campo system.

\section{Conclusions}

This study provides the first life cycle assessment of traditional Iberian pig production. Traditional Iberian pig production has lower climate change, eutrophication, acidification and cumulative energy demand impacts when relying on montanera fattening than when relying on cebo campo fattening. As a result, land occupation impact is increased with montanera fattening due to the use of large surfaces to provide natural resources to the animals. To our knowledge, it addresses for almost the first time the effect of emissions associated with the consumption of natural resources available on pasture and open woodlands on the level of the environmental impacts. The contribution of emissions derived from the consumption of natural resources to climate change, acidification and eutrophication impacts reached about $10 \%$. Therefore, they should be included in the LCA to avoid underestimation of the environmental impacts for systems in which natural resources are used. The greater use of natural resources seems to be an option for reducing the environmental impact of this system, which can reach values close to those obtained for conventional systems. This reduction of environmental impacts is mainly due to a reduction in the consumption of compound feed. Therefore, 
a better management of natural resources could reduce the dependence on compound feed and could make Iberian traditional pig production more environment-friendly. The traditional Iberian farms are also needed for the conservation of the ecosystem called dehesa. The preservation of the dehesa ecosystem through the conservation of traditional Iberian systems for the production of high-quality meat products may be achieved at limited environmental impacts through higher reliance on the natural resources provided by the dehesa ecosystem.

Supplementary Materials: The following are available online at http://www.mdpi.com/2071-1050/12/2/627/s1, File S1: Questionnaire carried out on participating farms, Table S1: Chemical composition of feed formulas and natural resources and feed ingredients incorporated into each feed formula, Table S2: Data Iberian pig farms.

Author Contributions: The authors have read and agreed to the published version of the manuscript. Conceptualization, J.G.-G., S.E., I.B.-P. and F.G.-L.; methodology, J.G.-G., A.N.T.R.M. and F.G.-L.; formal analysis, J.G.-G. and F.G.-L.; investigation, J.G.-G. and I.B.-P.; writing-original draft preparation, J.G.-G.; writing-review and editing, A.N.T.R.M., S.E., I.B.-P. and F.G.-L.; supervision, I.B.-P. and F.G.-L.; project administration, I.B.-P.; funding acquisition, I.B.-P. All authors have read and agreed to the published version of the manuscript.

Funding: This research was funded by National Institute for Agricultural and Food Research and Technology, grant number RTA2013-00063-C03-02. The APC was funded by French National Institute for Research in Agriculture and Environment.

Acknowledgments: The authors would like to thank POD Dehesa de Extremadura, AECERIBER, ACPA and farmers for their support and help and to the following scientific collaborators: G. Alonso (Nutega), D. Carrión (UCO) and R. Olea (UNAM).

Conflicts of Interest: The authors declare no conflicts of interest.

\section{References}

1. De Vries, M.; De Boer, I.J.M. Comparing environmental impacts for livestock products: A review of life cycle assessments. Livest. Sci. 2010, 128, 1-11. [CrossRef]

2. Steinfeld, H.; Gerber, P. Livestock production and the global environment: Consume less or produce better? Proc. Natl. Acad. Sci. USA. 2010, 107, 18237-18238. [CrossRef]

3. Eldesouky, A.; Mesias, F.J.; Elghannam, A.; Escribano, M. Can extensification compensate livestock greenhouse gas emissions? A study of the carbon footprint in Spanish agroforestry systems. J. Clean. Prod. 2018, 200, 28-38. [CrossRef]

4. McAuliffe, G.A.; Chapman, D.V.; Sage, C.L. A thematic review of life cycle assessment (LCA) applied to pig production. Environ. Impact Assess. Rev. 2016, 56, 12-22. [CrossRef]

5. Van Der Werf, H.M.G.; Petit, J.; Sanders, J. The environmental impacts of the production of concentrated feed: The case of pig feed in Bretagne. Agric. Syst. 2005, 83, 153-177. [CrossRef]

6. Nguyen, T.L.T.; Hermansen, J.E.; Mogensen, L. Environmental costs of meat production: The case of typical EU pork production. J. Clean. Prod. 2012, 28, 168-176. [CrossRef]

7. Basset-Mens, C.; Van der Werf, H.; Robin, P.; Morvan, T.; Hassouna, M.; Paillat, J.M.; Vertes, F. Methods and data for the environmental inventory of contrasting pig production systems. J. Clean. Prod. 2007, 15, 1395-1405. [CrossRef]

8. Halberg, N.; Hermansen, J.E.; Kristensen, I.S.; Eriksen, J.; Tvedegaard, N.; Petersen, B.M. Impact of organic pig production systems on CO2 emission, C sequestration and nitrate pollution. Agron. Sustain. Dev. 2010, 30, 721-731. [CrossRef]

9. Dourmad, J.Y.; Ryschawy, J.; Trousson, T.; Bonneau, M.; González, J.; Houwers, H.W.; Hviid, M.; Zimmer, C.; Nguyen, T.L.; Morgensen, L. Evaluating environmental impacts of contrasting pig farming systems with life cycle assessment. Animal 2014, 8, 2027-2037. [CrossRef]

10. Rudolph, G.; Hortenhuber, S.; Bochicchio, D.; Butler, G.; Brandhofer, R.; Dippel, S.; Dourmad, J.Y.; Edwards, S.; Fruh, B.; Meier, M.; et al. Effect of three husbandry systems on environmental impact of organic pigs. Sustainability 2018, 10, 3796. [CrossRef]

11. Pirlo, G.; Care, S.; Della Casa, G.; Marcheti, R.; Ponzoni, G.; Faeti, V.; Fantin, V.; Masoni, P.; Buttol, P.; Zerbinatti, L.; et al. Environmental impact of heavy pig production in a sample of Italian farms. A cradle to farm-gate analysis. Sci. Total Environ. 2016, 565, 576-585. [CrossRef] 
12. Bava, L.; Zucali, M.; Sandrucci, A.; Tamburini, A. Environmental impact of the typical heavy pig production in Italy. J. Clean. Prod. 2017, 140, 685-691. [CrossRef]

13. Espagnol, S.; Demartini, J. Environmental impacts of extensive outdoor pig production systems in Corsica. In Proceedings of the 9th International Conference Life Cycle Assessment Agri-Food Sector (LCA Food 2014), San Francisco, CA, USA, 8-10 October 2014; pp. 364-371.

14. Garcia-Launay, F.; Rouillon, V.; Faure, J.; Fonseca, A. Life Cycle Assessment of pig production systems of the Noir de Bigorre chain. In Proceedings of the IX Simposio Internacional Sobre El Cerdo Mediterráneo, Portalegre, Portugal, 3-5 November 2016; pp. 21-25. [CrossRef]

15. Monteiro, A.N.T.R.; Wilfart, A.; Utzeri, V.; Batorek, N.; Tomazin, U.; Nanni, L.; Čandek-Potokar, M.; Fontanesi, L.; Garcia-Launay, F. Environmental impacts of pig production systems using European local breeds: The contribution of carbon sequestration and emissions from grazing. J. Clean. Prod. 2019, 237, 117843. [CrossRef]

16. Rodríguez-Estévez, V.; García, A.; Peña, F.; Gómez, A.G. Foraging of Iberian fattening pigs grazing natural pasture in the dehesa. Livest. Sci. 2009, 120, 135-143. [CrossRef]

17. Benito, J.; Albarrán, A.; García-Casco, J.M. Extensive Iberian pig production grazing systems. In Proceedings of the 21st General Meeting of the European Grassland Federation, Badajoz, Spain, 3-6 April 2006; pp. 635-645.

18. Argemí-Armengol, I.; Villalba, D.; Ripoll, G.; Teixeira, A.; Álvarez-Rodríguez, J. Credence cues of pork are more important than consumers' culinary skills to boost their purchasing intention. Meat Sci. 2019, 154, 11-21. [CrossRef]

19. Registro Informativo de Organismos Independientes de Control del ibérico (RIBER). Available online: https://www.mapa.gob.es/es/alimentacion/temas/calidad-agroalimentaria/calidad-comercial/mesa-deliberico/riber-publico/ (accessed on 29 July 2019).

20. Real Decreto 1135/2002, de 31 de Octubre, Relativo a Las Normas Mínimas Para la Protección de Cerdos. Available online: https:/www.boe.es/buscar/pdf/2002/BOE-A-2002-22544-consolidado.pdf. (accessed on 30 May 2019).

21. Sistema Electrónico de Acceso al Banco de Datos de Referencia del Porcino Español (BDporc). Available online: http://www.bdporc.irta.es/ (accessed on 2 August 2019).

22. Duarte, J.L.; Hernández-García, F.I.; García-Gudiño, J.; Rodríguez-Ledesma, A.; Izquierdo, M. The effect of farrowing rate and number of piglets weaned per litter on production costs of commercial Iberian herds in Extremadura (Spain). Acta Argiculturae Slov. 2013, 4, 215-218.

23. Real Decreto 4/2014, de 10 de enero, por el que se aprueba la norma de calidad para la carne, el jamón, la paleta y la caña de lomo ibérico. Available online: https://www.boe.es/buscar/pdf/2014/BOE-A-2014-318consolidado.pdf. (accessed on 1 April 2019).

24. Garcia-Launay, F.; Van der Werf, H.M.G.; Nguyen, T.T.H.; Tutour, L.; Dourmad, J.Y. Evaluation of the environmental implications of the incorporation of feed-Use amino acids in pig production using Life Cycle Assessment. Livest. Sci. 2014, 161, 158-175. [CrossRef]

25. Wilfart, A.; Espagnol, S.; Dauguet, S.; Tailleur, A.; Gac, A.; Garcia-Launay, F. ECOALIM: A dataset of environmental impacts of feed ingredients used in animal production. PLoS ONE 2016, 11, e0167343. [CrossRef]

26. Spanish Ministry of Agriculture, Fishery and Food. Available online: https://www.mapama.gob.es/ (accessed on 24 October 2018).

27. García-Serrano, P.; Lucena, J.; Ruano, S.; Nogales, M. Guía Práctica de Fertilización Racional de los Cultivos en España, 1st ed.; Spanish Ministry of Agriculture, Fishery and Food: Madrid, Spain, 2009; pp. 123-179.

28. IPCC. N2O Emissions from Managed Soils, and CO2 Emissions from Lime and Urea Application. In Guidelines for National Greenhouse Gas Inventories; IGES: Kamiyamaguchi, Japan, 2006; pp. 2-33.

29. Sistema Español de Inventario de Emisiones. Available online: https://www.miteco.gob.es/es/calidad-yevaluacion-ambiental/temas/sistema-espanol-de-inventario-sei-/ (accessed on 14 May 2018).

30. Rivera-Ferre, M.G.; Edwards, S.A.; Mayes, R.W.; Riddoch, I.; Hovell, F.D.D.B. The effect of season and level of concentrate on the voluntary intake and digestibility of herbage by outdoor sows. Anim. Sci. 2001, 72, 501-510. [CrossRef]

31. Olea, J.; Verdasco, L.; Paredes, M. Características y producción de los pastos de las dehesas del SO de la Península Ibérica. Pastos 1990, 21, 131-156. 
32. Rodríguez-Estévez, V.; Sánchez-Rodríguez, M.; García, A.; Gómez-Castro, A.G. Feed conversion rate and estimated energy balance of free grazing Iberian pigs. Livest. Sci. 2010, 132, 152-156. [CrossRef]

33. Rodríguez-Estévez, V.; Sánchez-Rodríguez, M.; García, A.R.; Gómez-Castro, A.G. Average daily weight gain of Iberian fattening pigs when grazing natural resources. Livest. Sci. 2011, 137, 292-295. [CrossRef]

34. García-Valverde, R.; Nieto, R.; Lachica, M.; Aguilera, J.F. Effects of herbage ingestion on the digestion site and nitrogen balance in heavy Iberian pigs fed on an acorn-based diet. Livest. Sci. 2007, 112, 63-77. [CrossRef]

35. Vázquez, B.; García-Ciudad, A.; Petisco, C.; García-Criado, B. Interannual variations in phosphorus content of semiarid grasslands over a long time period. Grassl. Sci. Eur. 2008, 13, 634-636.

36. Fundación Española para el Desarrollo de la Nutrición Animal (FEDNA). Available online: http: //fundacionfedna.org/ (accessed on 20 October 2018).

37. Rigolot, C.; Espagnol, S.; Pomar, C.; Dourmad, J.Y. Modelling of manure production by pigs and NH3, N2O and $\mathrm{CH} 4$ emissions. Part I: Animal excretion and enteric $\mathrm{CH} 4$, effect of feeding and performance. Animal 2010, 4, 1401-1412. [CrossRef]

38. Freitas, A. Influencia do Nivel e Regime Alimentar em Pre-Acabamento Sobre Crescimento e Desenvolvimento do Porco Alentejano e suas Repercusssoes Sobre o Acabamento em Montanheira e com Alimento Comercial; University of Évora: Evora, Portugal, 1998.

39. Dourmad, J.Y.; Levasseur, P.; Daumer, M.L.; Hassouna, M.; Landrain, B.; Lemaire, N.; Loussouarn, A.; Salaün, Y.; Espagnol, S. Évaluation des rejets d'azote, phosphore, potassium, cuivre et zinc des porcs. RMT Elev. Environ. 2015, 1-26.

40. García-Valverde, R.; Nieto, R.; Aguilera, J.F. Effects of herbage ingestion upon ileal digestibility of amino acids in heavy Iberian pigs fed on an acorn-based diet. J. Anim. Physiol. Anim. Nutr. 2010, 94, 203-214. [CrossRef]

41. Rigolot, C.; Espagnol, S.; Robin, P.; Hassouna, M.; Béline, F.; Paillat, J.M.; Dourmad, J.Y. Modelling of manure production by pigs and NH3, N2O and CH4 emissions. Part II: Effect of animal housing, manure storage and treatment practices. Animal 2010, 4, 1413-1424. [CrossRef]

42. European Commission, Joint Research Centre, Institute for Environment and Sustainability. Characterisation Factors of the ILCD Recommanded Life Cycle Impact Assessment Methods. Database and Supporting Information, 1st ed.; Publications Office of the European Union: Luxembourg, 2012; pp. 7-12.

43. SimaPro Database Manual. Available online: https://www.pre-sustainability.com/download/ DatabaseManualMethods.pdf (accessed on 22 May 2017).

44. The Ecoinvent Database: Overview and Methodology, Data Quality Guideline for the Ecoinvent Database Version 3. Available online: https://www.ecoinvent.org (accessed on 20 May 2017).

45. Barszcz, M.; Skomiał, J. The development of the small intestine of piglets-Chosen aspects. J. Anim. Feed Sci. 2011, 20, 3-15. [CrossRef]

46. De Miguel, A.; Hoekstra, A.Y.; García-Calvo, E. Sustainability of the water footprint of the Spanish pork industry. Ecol. Indic. 2015, 57, 465-474. [CrossRef]

47. Basset-Mens, C.; Van Der Werf, H.M.G. Scenario-based environmental assessment of farming systems: The case of pig production in France. Agric. Ecosyst. Environ. 2005, 105, 127-144. [CrossRef]

48. González-García, S.; Belo, S.; Dias, A.C.; Rodrigues, J.V.; Da Costa, R.R.; Ferreira, A.; Pinto de Andrade, L.; Arroja, L. Life cycle assessment of pigmeat production: Portuguese case study and proposal of improvement options. J. Clean. Prod. 2015, 100, 126-139. [CrossRef]

49. Pelletier, N.; Lammers, P.; Stender, D.; Pirog, R. Life cycle assessment of high- and low-profitability commodity and deep-bedded niche swine production systems in the Upper Midwestern United State. Agric. Syst. 2010, 103, 599-608. [CrossRef]

50. Mackenzie, S.G.; Leinonen, I.; Ferguson, N.; Kyriazakis, I. Can the environmental impact of pig systems be reduced by utilising co-products as feed? J. Clean. Prod. 2016, 115, 172-181. [CrossRef]

51. Monteiro, A.N.T.R.; Garcia-Launay, F.; Brossard, L.; Wilfart, A.; Dourmad, J.Y. Effect of feeding strategy on environmental impacts of pig fattening in different contexts of production: Evaluation through life cycle assessment. J. Anim. Sci. 2016, 94, 4832-4847. [CrossRef]

52. Wilfart, A.; Dusart, L.; Méda, B.; Gac, A.; Espagnol, S.; Morin, L.; Dronne, Y.; Garcia-Launay, F. Réduire les impacts environnementaux des aliments pour les animaux d'élevage. INRA Prod. Anim. 2019, 31, 289-306. [CrossRef] 
53. Muñoz, M.; Bozzi, R.; García, F.; Núñez, Y.; Geraci, C.; Crovetti, A.; García-Casco, J.; Alves, E.; Škrlep, M.; Charneca, R.; et al. Diversity across major and candidate genes in European local pig breeds. PLoS ONE 2018, 13, 1-30. [CrossRef]

54. Rodríguez-Estévez, V.; Avilez, J.P.; Félix, E.; Perea, J.; García, A.; Gómez, G. Eficiencia del cerdo ibérico en el decorticado de la bellota. Arch. Zootec. 2007, 56, 535-539.

55. Stanley, P.L.; Rowntree, J.E.; Beede, D.K.; DeLonge, M.S.; Hamm, M.W. Impacts of soil carbon sequestration on life cycle greenhouse gas emissions in Midwestern USA beef finishing systems. Agric. Syst. 2018, 162, 249-258. [CrossRef]

(C) 2020 by the authors. Licensee MDPI, Basel, Switzerland. This article is an open access article distributed under the terms and conditions of the Creative Commons Attribution (CC BY) license (http://creativecommons.org/licenses/by/4.0/). 